Journal of Biotechnology and Strategic Health Research

Araştırma Makalesi / Research Article

http://dergipark.org.tr/tr/pub/bshr

\title{
Ranking OECD Countries By Using COVID-19 And Health Policy Variables with Fuzzy AHP And MULTIMOORA Methods
}

\author{
OECD ülkelerinin COVID-19 ve Sağlık Politikaları Değişkenlerine göre \\ Bulanık AHP ve MULTIMOORA Yöntemi İle Değerlendirilmesi
}

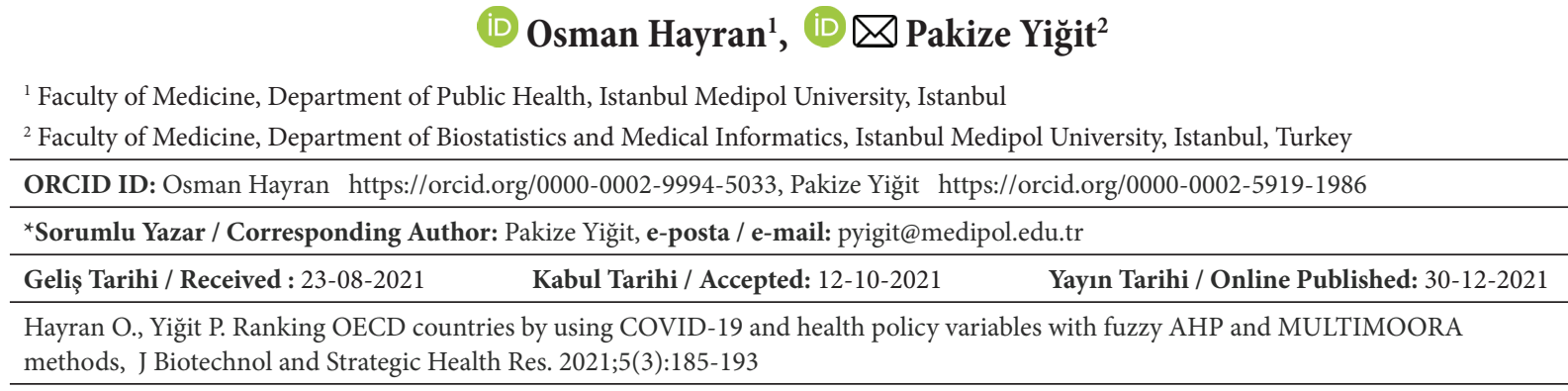

\footnotetext{
Özet

Amaç Çalışmanın amacı, OECD ülkelerinin COVID-19 için izlediği sağlık politikaları ve diğer ilișkili değişkenlere göre performansının MULTIMOORA yöntemi ile analizidir.

Materyal ve Çalışmada 37 OECD ülkesinin verileri kesitsel olarak incelenmiştir. Ülkelerinin COVID-19 dönemi performansını değerlendirilmesi için 11 değişken belirlenmiștir. Bu dönemde,

Metod ülkelerin belirlediği dokuz sağık politikasının Bulanık AHP yöntemi ile ağırlıkları hesaplanarak ülkeler için sağlık politikası skoru belirlenmisțir. Ardından, MULTIMOORA ile ülkelerin COVID-19 ilișkili performansları analiz edilmiștir.

Bulgular Ülkelerin dokuz COVID-19 ilişkili sağlık politikaları sıralandığında, 0,172 ile en yüksek puan "Sağlık çalışanlarını harekete geçirmek ve korumak", 0,042 en düşük puan ile "Akıl sağlığı hizmetlerine erişimi arttırmak” bulunuștur. MULTIMOORA ile yapılan COVID-19 pandemi yönetimi analizine göre ise, Yeni Zelanda en yüksek, Belçika en düşük, Türkiye ise on sekizinci sırada performansa sahip ülkeler olarak bulunmuștur.

Sonuc Calışma bulgularına göre, İzlanda ve Cek Cumhuriveti hariç, doğu bölgesinde yer alan ülkelerin performansının batı bölgesinde yer alan gelissmis ülkelerden daha iyi olduğu anlașılmaktadır. Ancak araștırmanın kesitsel yönteminin yanı sıra, değișkenlerin kendi arasındaki etkileșimleri nedeniyle, ülkelerin pandemiyi yönetmedeki başarı veya başarısızlığı hakkında iddialı sonuçlar çıkarmak doğru değildir.

Anahtar Analitik Hiyerarși Süreci, COVID-19, MULTIMOORA, OECD Ülkeleri, Sağlık Polikaları,

Özet

Aim The aim of this study is to compare performance rankings of OECD countries with the MULTIMOORA method by using the health policy responses and various variables related to COVID-19.

Material and Study includes cross-sectional data of 37 OECD countries. Data regarding eleven variables about the current population health status in these countries are collected from open reliable sources. CO-

Method VID-19 health policy responses of the countries recorded in the OECD database were scored and weighted scores computed by using Fuzzy AHP method. The performance rankings of OECD countries were determined by the MULTIMOORA method with use of all variables.

Results Among the policy responses highest ranking score was computed for "mobilizing and protecting health workers" and the lowest score for "increasing access to mental health services" ( 0,172 and 0,042 points respectively). According to the results of performance rankings by MULTIMOORA, New Zealand was located in the first and Belgium in the last place while Turkey has been the eighteenth.

Conclusion Study findings can be concluded as the COVID-19 performance of the Eastern countries is better than the Western developed countries with the exceptions of Iceland and Czechia. However, it is difficult to draw justifying conclusions about the success or failure of a country in managing the pandemic due to the complex interactions between various variables and the cross-sectional nature of the study data.

Keywords Fuzzy AHP, COVID-19, Health Policy, OECD Countries, SARS-CoV-2
} 


\section{INTRODUCTION}

Epidemics and pandemics of infectious disease have a long history and a continuing story. Global community has experienced important pandemics such as SARS, MERS, Ebola, swine flu in the first years of the 21st century and COVID-19 is the most recent one. On March 11, 2020, WHO declared the new SARS-CoV-2 outbreak which was formally identified as COVID-19, a global pandemic, after the novel coronavirus infected 118,000 individuals in 114 countries, and 4,291 people have lost their lives. ${ }^{1}$

Despite the increased frequency of pandemic events in the near past and repeated warnings of various experts, global community was not prepared for the next pandemics ${ }^{2}$. In an article published in 2017 it was emphasized that: "The global pandemic response has typically followed cycles of panic followed by neglect. We are now, once again, in a phase of neglect, leaving the world highly vulnerable to massive loss of life and economic shocks from natural or human-made epidemics and pandemics"3,4. As a matter of fact, the prophecy came true, and nowadays we are experiencing serious casualties and significant economic damage.

Preparedness of the health systems is an important issue since most epidemics and pandemics occur unexpectedly and it is obvious that majority of the health systems were not prepared for COVID-19. Especially during a pandemic caused by a new infectious agent, as is the case of COVID-19, there is no magic formula for management and control because of the unique epidemiologic characteristics and transmission dynamics. One may have high infectivity, as in the case of swine flu, another may have high fatality rates, as in the case of SARS. Current literature on pandemics and epidemics show that policies that are effective in one population may be not be effective in another due to several factors, such as, pathogenesis of the particular disease $\mathrm{e}^{5}$, the characteristics of the exposed population ${ }^{6,7}$ and the nature of the medical and communication techno$\log y$ at the time $e^{8,9}$.
Several policies and control measures have been discussed by the international community since the beginning of COVID-19 epidemic in China at the end of the year 2019 and following the announcement of it as a pandemic in March 20201,10,11. Governments worldwide have implemented numerous health policies and creating new ways to respond to the pandemic by announcing changes almost daily. Mitigation of the spread of the virus, treatment for those affected and early detection activities such as contact tracing and testing are among the most important health policy responses.

Management and control strategies for COVID-19 pandemic are largely based on the experiences of previous viral pandemics. There are two major groups of strategies: mitigation and suppression. Purpose of the mitigation is to preserve existing primary health care services while minimizing morbidity and mortality. On the other hand, suppression aims to prevent health care system collapse and imposes more severe, emergency restrictions and provide conditions for easing-off towards less intense mitigation strategies $^{12}$. Some nations preferred mitigation strategy at the beginning of the pandemic, while the majority preferred suppression in addition to mitigation. Each approach included various policies, such as, external border restriction, quarantine measure, curfew, lockdown, social distancing, mask using, contact tracing, research and development studies for vaccine and medicines, etc. The effectiveness and sustainability of these policies changed from nation to nation and time to time.

It is important to state that neither mitigation nor suppression approaches are choices on the opposite edges. In the presence of a strong surveillance system, it might be possible to successfully identify infected people, carry out contact tracing, and ensure isolation work properly in addition to using the approaches of mitigation and suppression together based on the continuous assessment of data $^{13}$. However, availability of reliable surveillance data is a significant problem for all nations. On the other hand, 
both of the mitigation and suppression strategies carry considerable social and economic costs, meaning that policymakers and the public at large only adopt them for short time periods ${ }^{14}$. Besides non-pharmaceutical control strategies several other health service regulations and implementation of new health policies are crucial during the pandemic. Adequacy and preparedness of the healthcare workers and health facilities; availability of and accessibility to diagnostic tests, protective equipment, ventilators, essential medicines; research capacity for development of vaccine and treatment; smarter use of data for surveillance and tracking; protection of the high-risk groups, are some examples of such health policies.

In our study we investigated the relationship between health policy responses, health system variables and COVID-19 pandemic measures of the OECD countries using Fuzzy Analytic Hierarchy Process (F-AHP) and ranked their performance by Multi-Objective Optimization by Ratio Analysis (MULTIMOORA) method.

\section{METHODOLOGY}

Our study includes cross-sectional data of 37 OECD countries on 09.11.2020. We identified eleven variables to summarize the current population health status in these countries. Five of the variables, fatality rate ${ }^{15}$, recovery rate $^{16}$, number of cases per million population ${ }^{15}$, number of deaths per million population ${ }^{15}$ and number of tests per million population ${ }^{17}$ were related with COVID-19 pandemic. Four variables, number of beds per 1000 inhabitants ${ }^{18}$, number of physicians per 1000 population, number of nurses per 1000 population and percentage of public health coverage were related with the healthcare infrastructure of the countries ${ }^{18,19}$. Tenth variable was the percentage of the elderly population ${ }^{18}$ as a high-risk group during the pandemic, and the health policy score of each country was the eleventh variable.

The most recent morbidity and mortality data regarding the COVID-19 pandemic, healthcare infrastructure data and percentage of the elderly population were obtained from various reliable online databases. Health policy areas were listed under 9 topics by OECD and the health system response of each country was recorded during the pandemic (Table 1). After scoring the countries' health system responses (implemented:1; nonimplemented:0), we calculated the normalized weights of the health policy scores by Fuzzy Analytic Hierarchy Process (F-AHP) according to the opinions of three experts from the COVID-19 Advisory Committee of Turkish Ministry of Health. (Table 3). Then we used the weighted health policy score as a new variable in the MULTIMOORA analysis.

The steps of the research methodology can be summarized as following:

Step-1: Determination of the study variables

Step-2: Finding the most recent reliable country statistics and implemented health policies

Step-3: Calculation of the health policy weights by F-AHP method according to expert opinions

Step-4: Using the weighted health policy score as a new variable

Step-5: Calculation of the weights of all indicators by F-AHP method and expert opinions

Step-6: Determination of the min and max effects of the indicators for MULTIMOORA

Step-7: Ranking the countries according to ratio system, reference point, and full multiplicative form methods Step-8: Finalization of the ranking of the countries according to MULTIMOORA

\begin{tabular}{|l|l|}
\hline \multicolumn{2}{|l|}{ Table 1: Health policy areas (Health system response) $)^{\mathbf{2 0}}$} \\
\hline P1 & accelerate R\&D for vaccines and treatment \\
\hline P2 & $\begin{array}{l}\text { encourage telemedicine, smarter use of data for surveillance and } \\
\text { tracking }\end{array}$ \\
\hline P3 & improve the affordability of diagnostics and treatment for all \\
\hline P4 & increase access to mental health services \\
\hline P5 & $\begin{array}{l}\text { increase supplies of diagnostic tests, protective equipment, ventila- } \\
\text { tors, essential medicines }\end{array}$ \\
\hline P6 & mobilize and protect health workers \\
\hline P7 & optimize hospital beds and spaces for diagnostics and treatments \\
\hline P8 & protection for the elderly \\
\hline P9 & additional funding/financing for the health system \\
\hline
\end{tabular}




\section{AHP and F-AHP}

Analytic Hierarchy Process (AHP) is an important Multiple Criteria Decision-Making (MCDM) technique established by Saaty in $1980^{21}$. It is a powerful tool to solve complex decision problems. It solves problems by turning into hierarchical structures through pairwise comparisons. Saaty describes respondents' feelings as exact numbers $(1,3,5,7,9)$. Although AHP is an extensive tool, it has some drawbacks ${ }^{22}$. Ranking of AHP results is imprecise because of its subjective judgment of decision-makers. Many researchers developed Fuzzy AHP that integrated the fuzzy theory and AHP to overcome this problem ${ }^{23-25}$. Fuzzy theory is a mathematical theory used to model fuzziness of the human cognitive process, so it is believed to allow researchers more accurate results ${ }^{22,26}$. In F-AHP, The pairwise comparisons are taken from decision-makers on their linguistic terms and a scale of ${ }^{1-9}$. Then, decision-makers' pairwise comparisons transformed into triangular fuzzy numbers ${ }^{24,27}$ as it is shown in Table-2.

\begin{tabular}{|l|c|c|c|}
\hline \multicolumn{1}{|c|}{ Table 2: Triangular fuzzy numbers used in the research } \\
\hline $\begin{array}{c}\text { Vinguistic } \\
\text { Variables }\end{array}$ & $\begin{array}{c}\text { Intensity of } \\
\text { importance }\end{array}$ & $\begin{array}{c}\text { Triangular } \\
\text { fuzzy numbers }\end{array}$ & $\begin{array}{c}\text { Reciprocal } \\
\text { triangular } \\
\text { fuzzy numbers }\end{array}$ \\
\hline Equally Strong & 1 & $1,1,1$ & $1,1,1$ \\
\hline Moderately & 3 & $2,3,4$ & $1 / 4,1 / 3,1 / 2$ \\
Strong & 5 & $4,5,6$ & $1 / 6,1 / 5,1 / 4$ \\
\hline Strong & 7 & $6,7,8$ & $1 / 8,1 / 7,1 / 6$ \\
\hline Very strong & 9 & $9,9,9$ & $1 / 9,1 / 9,1 / 9$ \\
\hline Extremely & & $7,8,9 ;$ & $1 / 9,1 / 8,1 / 7 ;$ \\
strong & $2,4,6,8$ & $\begin{array}{c}5,6,7 ; \\
3,4,5 ;\end{array}$ & $1 / 7,1 / 6,1 / 5 ;$ \\
\hline & & $1,2,3$ & $1 / 3,1 / 2,1$ \\
\hline Intermediate & & & \\
& & &
\end{tabular}

\section{MOORA and MULTIMOORA Methods}

The Multi-Objective Optimization by Ratio Analysis (MOORA) is one of the powerful Multi Criteria Decision Making (MCDM) techniques that was first developed by Brauers and Zavadskas ${ }^{28}$. Later Brauers and Zavadskas added the full multiplicative form to the MOORA and the new method was called MULTIMOORA ${ }^{29,30}$. It requires a matrix of responses of the alternatives to the objectives.
Then a ratio system is developed in which each response of an alternative on an objective is compared to a denominator, which is the representative for all alternatives concerning that objective ${ }^{31}$.

MOORA contains ratio system and reference point methods. MULTIMOORA consists of both MOORA and full multiplicative form.

\section{RESULTS}

\section{Determination of Health Policy Score by F-AHP:}

Average and normalized weights of the Health Policy scores for the countries according to F-AHP are presented in Table 3. As it is seen from the table, P6 (mobilization and protection of health workers) is the most essential health system response to COVID-19 (normalized weight: $17,27 \%)$. It was followed by P1 (accelerate R\&D for vaccines and treatment), P7 (optimize hospital beds and spaces for diagnostics and treatments) and P5 (increase supplies of diagnostic tests, protective equipment, ventilators, essential medicines) $(13.34 \%, 13.31 \%, 12.53 \%$ respectively). P4 (increase access to mental health services) has the lowest weight among HPs.

Australia, France, Ireland, Japan, Portugal, Turkey, and the United Kingdom were the countries with highest health policy scores because they implemented all of the nine policies while Sweden had the lowest health policy score and it implemented just P5 and P9. 
J Biotechnol and Strategic Health Res. 2021;5(3):185-193

HAYRAN, YİĞİT, Ranking OECD Countries by COVID-19 indicators

\begin{tabular}{|l|c|c|c|}
\hline \multicolumn{5}{|c|}{ Table 3: Average and normalized weights of Health Policies } \\
\hline P1 & accelerate R\&D for vaccines and treatment & 0,1359 & 0,1334 \\
\hline P2 & $\begin{array}{r}\text { encourage telemedicine, smarter use of data for } \\
\text { surveillance and tracking }\end{array}$ & 0,1209 & 0,1186 \\
\hline P3 & $\begin{array}{r}\text { improve the affordability of diagnostics and } \\
\text { treatment for all }\end{array}$ & 0,1147 & 0,1126 \\
\hline P4 & increase access to mental health services & 0,0420 & 0,0412 \\
\hline P5 & $\begin{array}{c}\text { increase supplies of diagnostic tests, protective } \\
\text { equipment, ventilators, essential medicines }\end{array}$ & 0,1276 & 0,1253 \\
\hline P6 & mobilize and protect health workers & 0,1760 & 0,1727 \\
\hline P7 & $\begin{array}{c}\text { optimize hospital beds and spaces for diagnos- } \\
\text { tics and treatments }\end{array}$ & 0,1356 & 0,1331 \\
\hline P8 & protection for the elderly & 0,1146 & 0,1125 \\
\hline P9 & additional funding/financing for the health & 0,0515 & 0,0505 \\
\hline
\end{tabular}

In Table 4, weights of the all study variables calculated by F-AHP are presented. Deaths per million population has the highest weight $(26,46 \%)$ and it is followed by cases per million population (17,35\%). Hospital beds per thousand population has the lowest weight (2,50\%) among all study variables.

\begin{tabular}{|l|c|c|}
\hline \multicolumn{2}{|l|}{ Table 4: Weights of the selected variables calculated by F-AHP } \\
\hline Variables & Weights & $\begin{array}{c}\text { Desirable } \\
\text { Value }\end{array}$ \\
\hline Case Fatality Rate & 0,106749276 & Min \\
\hline Recovery Rate & 0,060623448 & Max \\
\hline Cases/1m population & 0,173476596 & Min \\
\hline Deaths/1m population & 0,264665339 & Min \\
\hline Tests/1m population & 0,083269484 & Max \\
\hline Elderly population, \% of population & 0,056620202 & Min \\
\hline Hospital beds, per 1.000 inhabitants & 0,025045358 & Max \\
\hline Physicians, per 1.000 inhabitants & 0,041154315 & Max \\
\hline Nurses, per 1.000 inhabitants & 0,029890754 & Max \\
\hline $\begin{array}{l}\text { Population coverage for a core set of } \\
\text { services (Total Public Coverage) }\end{array}$ & 0,052193708 & Max \\
\hline Health Policy Score & 0,106311519 & Max \\
\hline
\end{tabular}

\section{MULTIMOORA Results}

We created a response matrix for our variables and then converted the elements of the matrix and by using the summarizing indexes we ranked the countries according to the ratio scale, the reference point method, the full multiplicative form and the MULTIMOORA method. These findings are presented in Table 5.

As it is seen from the table New Zealand shows absolute dominance on the other countries for study variables. Countries can be summarized in three groups according to our study indicators for COVID-19 performance: best performance (holding ranks 1-12), medium performance (rank 13-24), and low performance (rank 25-37).

New Zealand, Iceland, Australia, Czechia, South Korea, Japan are the countries with highest performance according to MULTIMOORA, while Belgium, Chile, Italy, United States, Sweden and Spain are the lowest ranked countries.

Table 5: Ranks of OECD Countries' according to ratio scale, reference point and MULTIMOORA

\section{DISCUSSIONS and CONCLUSIONS}

In this study we investigated the performance of OECD countries during COVID-19 pandemic. We compared member countries with regard to a group of variables about their health system infrastructure, health system response and COVID-19 follow-up indicators. Because of the complexity of such a multivariable comparison we used F-AHP and MULTIMOORA methods which are useful Multiple Criteria Decision-Making methods. New Zealand, Iceland, Australia, Czechia, South Korea, Japan are the countries with highest performance, while Belgium, Chile, Italy, United States, Sweden and Spain are the lowest ranked countries according to study findings. This finding can be concluded as the performance of eastern developed countries is better than western developed countries with the exceptions of Iceland and Czechia.

Our F-AHP findings indicated that mobilization and protection of health workers is the most essential health system response to COVID-19 (normalized weight: $17,27 \%$ ) which was implemented by 32 of the 37 member states. It was followed by "accelerating R\&D for vaccines and treatment", "optimizing hospital beds and spaces 
J Biotechnol and Strategic Health Res. 2021;5(3):185-193

HAYRAN, YİĞİT, Ranking OECD Countries by COVID-19 indicators

\begin{tabular}{|c|c|c|c|c|c|c|c|}
\hline Countries & $\begin{array}{l}\text { Ratio } \\
\text { Scale }\end{array}$ & Rank & $\begin{array}{c}\text { Reference } \\
\text { Point }\end{array}$ & Rank & $\begin{array}{c}\text { Full } \\
\text { Multiplicative } \\
\text { Form }\end{array}$ & Rank & $\begin{array}{r}\text { MULTI } \\
\text { MOORA }\end{array}$ \\
\hline Australia & 0,947794508 & 6 & 0,509347903 & 7 & $1,43 \mathrm{E}+00$ & 4 & 3 \\
\hline Austria & 0,782249392 & 11 & 0,581327564 & 20 & 7,79E-02 & 15 & 16 \\
\hline Belgium & $-0,068761172$ & 35 & 0,538218249 & 9 & $3,04 \mathrm{E}-04$ & 32 & 37 \\
\hline Canada & 0,409900126 & 25 & 0,574633713 & 16 & $3,67 \mathrm{E}-03$ & 25 & 24 \\
\hline Chile & 0,035836631 & 32 & 0,581986924 & 22 & $8,52 \mathrm{E}-04$ & 28 & 36 \\
\hline Colombia & 0,046406733 & 31 & 0,631396536 & 33 & $7,03 \mathrm{E}-05$ & 34 & 29 \\
\hline Czechia & 0,97945101 & 3 & 0,371293605 & 3 & $8,01 \mathrm{E}-01$ & 5 & 4 \\
\hline Denmark & 0,646530975 & 15 & 0,568350602 & 14 & $2,74 \mathrm{E}-02$ & 18 & 20 \\
\hline Estonia & 0,665309754 & 13 & 0,592543559 & 25 & $9,28 \mathrm{E}-02$ & 14 & 15 \\
\hline Finland & 0,718278441 & 12 & 0,583618425 & 23 & $1,04 \mathrm{E}-01$ & 13 & 14 \\
\hline France & 0,255019516 & 27 & 0,578868855 & 19 & $9,96 \mathrm{E}-04$ & 26 & 28 \\
\hline Germany & 0,883463005 & 8 & 0,574784948 & 17 & $1,16 \mathrm{E}-01$ & 12 & 13 \\
\hline Greece & 0,614133373 & 17 & 0,604650922 & 27 & $6,42 \mathrm{E}-02$ & 16 & 11 \\
\hline Hungary & 0,463528998 & 24 & 0,634678442 & 34 & $9,76 \mathrm{E}-03$ & 22 & 22 \\
\hline Iceland & 1,094506377 & 2 & 0,32002451 & 2 & $2,04 \mathrm{E}+00$ & 3 & 2 \\
\hline Ireland & 0,49024495 & 23 & 0,555281983 & 12 & $5,36 \mathrm{E}-03$ & 24 & 23 \\
\hline Israel & 0,391097603 & 26 & 0,496148099 & 4 & $1,96 \mathrm{E}-02$ & 20 & 26 \\
\hline Italy & $-0,069966247$ & 36 & 0,573540699 & 15 & $3,25 \mathrm{E}-04$ & 31 & 35 \\
\hline Japan & 0,968954491 & 5 & 0,658870826 & 36 & $7,05 \mathrm{E}-01$ & 7 & 6 \\
\hline Korea, South & 0,974150173 & 4 & 0,642648621 & 35 & $4,71 \mathrm{E}+00$ & 2 & 5 \\
\hline Latvia & 0,660447922 & 14 & 0,581762363 & 21 & $3,90 \mathrm{E}-01$ & 9 & 10 \\
\hline Lithuania & 0,7850458 & 10 & 0,520093581 & 8 & $4,29 \mathrm{E}-01$ & 8 & 7 \\
\hline Luxembourg & 1,152580396 & 1 & 0,269824587 & 1 & $1,31 \mathrm{E}-01$ & 11 & 9 \\
\hline Mexico & $-0,072166982$ & 37 & 0,659896242 & 37 & $1,65 \mathrm{E}-05$ & 35 & 31 \\
\hline Netherlands & 0,081723239 & 30 & 0,605356683 & 28 & $1,10 \mathrm{E}-06$ & 36 & 27 \\
\hline New Zealand & 0,86911323 & 9 & 0,567590419 & 13 & $1,83 \mathrm{E}+01$ & 1 & 1 \\
\hline Norway & 0,886879089 & 7 & 0,575843017 & 18 & $2,71 \mathrm{E}-01$ & 10 & 8 \\
\hline Poland & 0,562103718 & 21 & 0,621613832 & 31 & $2,10 \mathrm{E}-02$ & 19 & 21 \\
\hline Portugal & 0,608702969 & 18 & 0,541248097 & 10 & $1,40 \mathrm{E}-02$ & 21 & 17 \\
\hline Slovakia & 0,625396957 & 16 & 0,626252267 & 32 & $7,70 \mathrm{E}-01$ & 6 & 12 \\
\hline Slovenia & 0,596378414 & 19 & 0,61610408 & 30 & $3,75 \mathrm{E}-02$ & 17 & 19 \\
\hline Spain & 0,097344745 & 29 & 0,544233262 & 11 & $6,43 \mathrm{E}-04$ & 29 & 32 \\
\hline Sweden & 0,013089638 & 33 & 0,59575042 & 26 & $1,30 \mathrm{E}-04$ & 33 & 33 \\
\hline Switzerland & 0,558483031 & 22 & 0,588150308 & 24 & 0 & 37 & 25 \\
\hline Turkey & 0,580699476 & 20 & 0,608848828 & 29 & $9,28 \mathrm{E}-03$ & 23 & 18 \\
\hline United Kingdom & 0,100995792 & 28 & 0,503957305 & 5 & $9,04 \mathrm{E}-04$ & 27 & 30 \\
\hline United States & $-0,037042904$ & 34 & 0,507348054 & 6 & $3,74 \mathrm{E}-04$ & 30 & 34 \\
\hline
\end{tabular}


for diagnostics and treatments" and "increasing supplies of diagnostic tests, protective equipment, ventilators, essential medicines" (normalized weights:13.34\%, 13.31\%, $12.53 \%$ respectively). "Increasing access to mental health services" has the lowest weight among the implemented health policies. Adequacy of health workers in terms of both quantitatively and qualitatively, seem to be number one health policy response during this pandemic. In some countries, pharmacists, dentists and care assistants were mobilized, in others, medical students in their last year of training were allowed to start working for contact tracing and case finding activities. It is interesting that some developed countries suffered from insufficiency of face-masks, protective equipment, diagnostic tests and ventilators. As of 24 October, over 41 million cases and 1.1 million deaths have been reported globally ${ }^{32}$. Due to the complexity of interactions between various variables, it is difficult to draw justifying conclusions about the success or failure of a country in managing a pandemic.

As it was stated by Colombo and Clark in a recent document of WEF, the crisis poses a major threat to the global economy, with drops in activity, employment, and consumption worse than those seen during the 2008 financial crisis. COVID-19 has also exposed weaknesses in our health systems that must be addressed ${ }^{33}$.

Besides economic threats and lost lives, the health system response to COVID-19 has resulted in negative effects on the delivery of routine health services. Decreases in immunization coverage rates, difficulties with the management of non-communicable diseases, are some problems due to at least partially replacement of health workers prioritized to the COVID-19 response ${ }^{34}$.

The goal of every healthcare systems around the world is to make affordable high-quality healthcare available and accessible for everybody. However, it is becoming increasingly costly to provide availability and accessibility, due to rapid changing medical technologies, demographic transition of the populations and the increasing burden of non-communicable diseases. Even before COVID-19, 800 million people faced catastrophic healthcare costs, 100 million families were pushed into poverty every year due to high rates of out-of-pocket spending on health, and millions more simply avoided care for critical conditions because they could not afford to pay for it ${ }^{33}$.

COVID-19 deaths per million population was 5 in New Zealand, first of our ranking list and 925 in Belgium, the last of the list, on 25th of October 2020 which means citizens of a developed western European country had died 185 times more than the citizens of New Zealand during this pandemic ${ }^{35}$.

As it was stated in a recent publication about avoidable COVID-19 deaths, underlying causes of excess deaths are related with a confluence of factors, stemming from delayed responses, to missed opportunities, to inadequate guidance, coordination, and leadership ${ }^{36}$. It is clear that coping with pandemic is a matter of healthcare management more than medicine.

\section{Limitations of the study}

One important limitation of our study was the availability of reliable data. Data is important for decision making and to find reliable data is a serious problem during pandemic due to a series of political, epidemiological, statistical and methodological issues. The variations among the structure and reliability of the country health information systems; definitions of "case", "patient" and "death"; sensitivity and specificity of the diagnostic tests; amount of diagnostic testing and effectiveness of contact tracing are some factors that have significant influences on the quality of the collected data. However, because pandemic is a global health problem concerning health of all, we needed to trust the open source databases and reported statistics by the international organizations.

Another limitation of the study is its cross-sectional natu- 
J Biotechnol and Strategic Health Res. 2021;5(3):185-193

re. Causal conclusions should be done carefully due to the cross-sectional nature of the study. Measuring and understanding the causes of the performance of a country during pandemic is a multifactorial and complex issue. Prospective studies are the most appropriate methods to observe the influences of several variables on the study outcomes.

\section{Acknowledgments}

We would like to thank Emre Yilmaz for his collaboration.

\section{Declaration of interests}

The authors declare that they have not any competing financial interests or personal relationships that could have appeared to influence the work reported in this paper.

\section{Ethical Approval}

No ethical approval is required for this study. 
J Biotechnol and Strategic Health Res. 2021;5(3):185-193

HAYRAN, YİĞİT, Ranking OECD Countries by COVID-19 indicators

\section{Kaynaklar}

1. Li Q, Guan X, Wu P, et al. Early transmission dynamics in Wuhan, China, of novel coronavirus-infected pneumonia. N Engl J Med. 2020;382(13):1199-1207. doi:10.1056/ NEJMoa2001316

2. WHO. "The world is not prepared for a pandemic,." WHO. Published 2020. https://www. who.int/news/item/01-10-2020-the-best-time-to-prevent-the-next-pandemic-is-nowcountries-join-voices-for-better-emergency-preparedness

3. Yamey G, Schäferhoff M, Aars OK, et al. Financing of international collective action for epidemic and pandemic preparedness. Lancet Glob Heal. 2017;5(8):e742-e744. doi:10.1016/S2214-109X(17)30203-6

4. Organisation for Economic Co-operation and Development. Strengthening health systems during a pandemic: The role of development finance. Tackling Coronavirus (COVID-19). 2020;(June):1-24.

5. Kilbourne ED. Influenza pandemics of the 20th century. Emerg Infect Dis. 2006;12(1):914. doi:10.3201/eid1201.051254

6. Farmer P. Social Inequalities and Emerging Infectious Diseases. Emerg Infect Dis. 1996;2(4):259-269. doi:10.3201/eid0204.960402

7. Bavel JJV, Baicker K, Boggio PS, et al. Using social and behavioural science to support COVID-19 pandemic response. Nat Hum Behav. 2020;4(5):460-471. doi:10.1038/s41562020-0884-z

8. Bandayrel K, Lapinsky S, Christian M. Information technology systems for critical care triage and medical response during an influenza pandemic: a review of current systems. Disaster Med Public Health Prep. 2013;7(3):287-291. doi:10.1001/dmp.2011.45

9. Chew C, Eysenbach G. Pandemics in the age of Twitter: Content analysis of tweets during the 2009 H1N1 outbreak. PLoS One. 2010;5(11):1-13. doi:10.1371/journal.pone.0014118

10. Huang C, Wang Y, Li X, et al. Clinical features of patients infected with 2019 novel coronavirus in Wuhan, China. Lancet. 2020;395(10223):497-506.

11. Timeline of WHO's response to COVID-19. https://www.who.int/emergencies/diseases/ novel-coronavirus-2019/interactive-timeline (September 2020)

12. Walker PGT, Whittaker C, Watson OJ, et al. The impact of COVID-19 and strategies for mitigation and suppression in low- And middle-income countries. Science (80- ). 2020;369(6502):413-422. doi:10.1126/science.abc0035

13. Kayı İ, Sakarya S. Policy Analysis of Suppression and Mitigation Strategies in the Management of an Outbreak Through the Example of COVID-19 Pandemic. Infect Dis Clin Microbiol. 2020;2(1):30-41. doi:10.36519/idcm.2020.0009

14. Hsiang S, Allen D, Annan-Phan S, et al. The effect of large-scale anti-contagion policies on the COVID-19 pandemic. Nature. 2020;584(7820):262-267. doi:10.1038/s41586-0202404-8

15. Data OW in. Coronavirus Pandemic (COVID-19) - Statistics and Research - Our World in Data. https://ourworldindata.org/coronavirus

16. COVID-19 Corona Tracker. Published 2020. https://www.coronatracker.com/ (October, 2020)

17. Worldometer. Coronavirus Cases. Worldometer. doi:10.1101/2020.01.23.20018549V2

18. OECD. OECD Statistics. https://stats.oecd.org/ (September 2020)

19. OECD iLibrary | Population coverage for health care. (September, 2020)

20. Tackling the coronavirus (COVID-19) crisis together: OECD policy contributions for co-ordinated action.

21. Saaty TL. The analytic hierarchy process: planning. Prior Setting Resour Alloc MacGraw-Hill, New York Int B Co. Published online 1980.

22. Yang CC, Chen BS. Key quality performance evaluation using fuzzy AHP. J Chinese Inst Ind Eng. 2004;21(6):543-550. doi:10.1080/10170660409509433

23. van Laarhoven PJM, Pedrycz W. A fuzzy extension of Saaty's priority theory. Fuzzy Sets Syst. 1983;11(1-3):229-241. doi:10.1016/S0165-0114(83)80082-7

24. Buckley JJ. Fuzzy hierarchical analysis. Fuzzy Sets Syst. 1985;17(3):233-247. doi:10.1016/0165-0114(85)90090-9

25. Chang DY. Applications of the extent analysis method on fuzzy AHP. Eur J Oper Res. 1996;95(3):649-655. doi:10.1016/0377-2217(95)00300-2

26. Vahidnia MH, Alesheikh AA, Alimohammadi A. Hospital site selection using fuzzy AHP and its derivatives. J Environ Manage. 2009;90(10):3048-3056. doi:10.1016/j.jenvman.2009.04.010

27. Singh A, Prasher A. Measuring healthcare service quality from patients' perspective: using Fuzzy AHP application. Total Qual Manag Bus Excell. 2019;30(3-4):284-300. doi :10.1080/14783363.2017.1302794

28. Willem Karel Brauers, Kazimieras Zavadskas E. The MOORA method and its application to privatization in a transition economy. Control Cybern. 2006;35(2):445-469.

29. Brauers WKM, Zavadskas EK. Project management by multimoora as an instrument for transition economies. Technol Econ Dev Econ. 2010;16(1):5-24. doi:10.3846/tede.2010.01

30. Brauers WKM, Zavadskas EK. Multimoora optimization used to decide on a bank loan to buy property. Technol Econ Dev Econ. 2011;17(1):174-188. doi:10.3846/13928619.2 011.560632

31. Aytaç Adalı E, Tuș Ișık A. The multi-objective decision making methods based on MULTIMOORA and MOOSRA for the laptop selection problem. J Ind Eng Int. 2017;13(2):229-237. doi:10.1007/s40092-016-0175-5

32. Weekly operational update on COVID-19 - 23 October 2020

33. How to build a better health system: 8 expert essays | World Economic Forum.

34. Tan-Torres Edejer T, Hanssen O, Mirelman A, et al. Projected health-care resource needs for an effective response to COVID-19 in 73 low-income and middle-income countries: a modelling study. Lancet Glob Heal. 2020;8(11):e1372-e1379. doi:10.1016/S2214109X(20)30383-1

35. COVID-19 Virus Pandemic - Worldometer. (October, 2020)

36. Redlener BI, Sachs JD, Hansen S, Hupert N. AND COUNTING - IN THE U . S .. Published online 2020:0-12. 